Short notes and reviews

\title{
Amphibians and reptiles of Vietnam
}

\author{
Miguel Vences \\ Zoological Museum, University of Amsterdam, Mauritskade 57, 1092 AD Amsterdam, Netherlands
}

Review of: Die Amphibien und Reptilien eines Tieflandfeuchtwald-Schutzgebietes in Vietnam. By Thomas Ziegler. Natur und Tier-Verlag, Münster, 2002. ISBN 3-931587-54-1

Considered as one of the worldwide hotspots for biodiversity conservation (Myers et al., 2001), Vietnam has been the aim of recent expeditions of several major European research institutes, such as the Muséum national d'Histoire naturelle in Paris (Ohler et al., 2000), the Russian Academy of Sciences in St. Petersburg (e.g., Orlov et al., 2000), or the National Museum Leiden (Anonymous, 2002). The high zoological interest of Vietnam is exemplified by the recent discoveries of several new large mammal species. Although one of these, the bovid Pseudonovibos spiralis, is most probably non-existing but based on fake horns (Feiler et al., 2002; Olson and Hassanin, 2003), the fact that three new ungulate species could be added to Vietnam's megafauna in less than 10 years loses little of its impact (Pseudoryx nghetinhensis, Megamuntiacus vuquangensis, Muntiacus truongsonensis; Vu Van Dung et al., 1993; Pham Mong Giao et al., 1998; Do Tuoc et al., 1994).

Thomas Ziegler visited Vietnam during several months in 1997 and 1998. He carried out fieldwork in the lowland rainforests of the Ky Anh - Ke Go nature reserve in southern North-Vietnam, with the aim of gathering data for his $\mathrm{PhD}$ thesis on the amphibians and reptiles of this region. The book reviewed here is an expanded version of his $\mathrm{PhD}$ thesis. On 342 pages, printed in small fonts", and aided by 50 graphs and maps, 70 tables and 382 impressive and excellently reproduced colour photos, the author provides a detailed and comprehensive regional herpetofauna. Knowing Ziegler's extreme accurateness in investigating and writing, I did not try to find typing errors or similar minor mistakes (I'once proofread carefully the complete 210 pages [!] of his Diplom thesis, only to find two [!!] typos). There is little doubt that the data in this book are very reliable and that the bibliography is exhaustive and correctly cited.

The book's main characteristic is being highly descriptive. This is its strength but also sometimes a shortcoming. It is a strength because, in the chapters devoted to each of the 31 amphibian and 58 reptile species recorded from the study area, the author does not simply quote general information from other sources, but instead provides precise descriptions of morphology, colouration, bioacoustics (for the frogs) and ecology of the specimens observed. These data are contrasted with reports from the literature, but there never is any doubt which observations have been extracted from the references and which are original. All of the descriptions are very precise, and enriched by unexpected details (such as the stomach content analyses of most amphibians and some reptiles, or the determination of tadpoles by means of DNA sequences). For each species, the type locality is mentioned and the original description cited. The collected material is listed with locality information and collecting dates. Call descriptions of frogs are illustrated by high-quality sonagrams and oscillograms. For several squamates, the hemipenes are illustrated by photographs. Altogether, the amount of information is impres- 
sive and overwhelming.

The highly descriptive nature of the book, however, sometimes is also a weakness where more general discussions are to be expected. In the discussion, Ziegler provides useful summaries of his observations, but even this part is more synthetic than analytical. Some of his observations are striking, such as the very high number of snakes in the area (26 species $-57 \%$ of the reptiles, more than doubling the number of lizards and even outnumbering the amphibians) or the high incidence of antand termite-eating frogs. These findings claim for future comprehensive comparisons with other worldwide herpetofaunal communities, in order to detect common patterns and differences. Also the report on the local trade in protected and unprotected amphibians and reptiles (and other animals) is very useful and detailed. However, the author should be encouraged to provide, in future contributions, a more extensive discussion about the pros and contras of alternative conservation strategies, i.e., legal measures versus sustainable harvesting, under the local Vietnamese conditions.

As exposed in the introduction, next to characterizing the regional herpetofauna of the Ky Anh $\mathrm{Ke}$ Go reserve, one major aim of the book was to provide an updated summary of recent Vietnamese works on amphibians and reptiles. This "hidden literature" includes regional checklists as well as determination keys which are written in Vietnamese and therefore are virtually unavailable to the international scientific community. Ziegler translated all these works and provides extensive summaries, partly by reproducing complete tables. This undertaking is very important and laudable; iropically, it is shadowed by the language of Ziegler's book, which is entirely in German, and thereby leaves most of the painstaking translations inaccessible to a large part of worldwide herpetologists. In summary, there is no doubt that this book deserves a prominent place on the bookshelf of everybody interested in the herpetofauna of South-East Asia, be it in terms of ecology, biogeography or taxonomy. For those unfamiliar with German lan- guage, the excellent illustrations and graphs will provide sufficient information on many aspects. A wealth of original data is provided, and literature is summarized for almost 100 amphibian and reptile species. Ziegler's work will certainly serve for years to come as a valuable source, especially for herpetologists in search of reliable regional accounts from which bits of data can be extracted for comparative purposes.

\section{References}

Anonymous. 2002. Naturalis, Nationaal Natuurhistorisch Museum - Jaarverslag 2001. Leiden.

Do Tuoc, Vu Van Dung, Dawson S, Arctander P, Mackinnon J. 1994. Introduction of a new large mammal species in Vietnam. Thong tin kho hoc ky thuat, Hanoi, 3: 4-13 (in Vietnamese).

Feiler A, Ziegler T, Ansorge H, Nadler T. 2002. Pseudonovibos spiralis - Mythos oder Wirklichkeit ? ZGAP Mitteilungen 18: 21-24

Myers N, Mittermeier RA, Mittermeier CG, de Fonseca GAB, Kent J. 2000. Biodiversity hotspots for conservation priorities. Nature 403: 853-858.

Ohler A, Marquis O, Swan S, Grosjean S. 2000. Amphibian biodiversity of Hoang Lien Nature Reserve (Lao Cai Province, northern Vietnam) with description of two new species. Herpetozoa 13: 71-87.

Olson LE, Hassanin A. 2003. Contamination and chimerism are perpetuating the legend of the snake-eating cow with twisted horns (Pseudonovibos spiralis). A case study of the pitfalls of ancient DNA. Mol. Phylogenet. Evol. 27: $545-548$.

Orlov NL, Murphy RW, Papenfuss TJ. 2000. List of snakes of Tam-Dao mountain ridge (Tonkin, Vietnam). Russ. J. Herpetol. 7: 69-80.

Pham Mong Giao, Do Tuoc, Vu Van Dung, Wikramanayake ED, Amato G, Arctander P, MacKinnon JR. 1998. Description of Muntiacus truongsonensis, a new species of muntjac (Artiodactyla: Muntiacidae) from central Vietnam, and implications for conservation. Animal Conservation 1: 61-68.

Vu Van Dung, Pham Mong Giao, Nguyen Ngoc Chinh, Do Tuoc, Arctander P, MacKinnon JR. 1993. A new species of living bovid from Vietnam. Nature 363: 443445.

Received: 3 October 2003 